\title{
Effect of Three Irrigation Frequencies on Physiological-Biological Aspects of Young Olive Trees (Olea europaea L. cvs 'Koroneiki' and 'Picholine'): Vegetative Growth, Leaf Turgor Pressure, and Fluorescence
}

\author{
Abderrahman Sghaier ${ }^{1,2 *}$, Hechmi Chehab ${ }^{3}$, Feten Aissaoui ${ }^{3,4}$, Kamel Naggaz ${ }^{2}$, \\ Mohamed Ouessar ${ }^{2}$, Dalenda Boujnah ${ }^{3}$ \\ ${ }^{1}$ Faculty of Sciences of Gabes, University of Gabes, Gabes, Tunisia \\ ${ }^{2}$ Institut des Régions Arides (IRA), Médenine, Tunisia \\ ${ }^{3}$ Laboratoire d'Amélioration de la Productivité de l'Olivier et de la Qualité des Produits, \\ Institut de l'olivier, Unité Spécialisée de Sousse, Sousse, Tunisia \\ ${ }^{4}$ Institut Supérieur Agronomique de Chott Mariem, Sousse, Tunisia
}

Received: 17 January 2018

Accepted: 1 March 2018

\begin{abstract}
In arid and semi-arid areas, farmers are experiencing unprecedented water scarcity, which is likely to increase by the perspective of global warming. The purpose of this study was to evaluate the effect of three irrigation frequencies on vegetative growth, leaf turgor pressure, and photosynthesis of young olive trees (Olea europaea L. cvs 'Koroneiki' and 'Picholine'). We found that throughout the experiment and for all irrigation treatments, Picholine cultivar showed a higher rate of vegetative growth. In addition, the leaf turgor pressure for this cultivar showed fewer signs of stress overall as it recorded less Pp curve inversions during summer. However, during this season the photochemical efficiency in Picholine for the frequencies $\mathrm{T} 1$ and $\mathrm{T} 2$ were lower than Koroneiki by $9.53 \%$ and $10.63 \%$, respectively. Which implied that the non-stomatal limitation of photosynthesis has an impact on Picholine photosynthetic production, which in turn indicates that this cultivar is more sensitive to high temperature. Moreover, irrigation frequency has little effect on the Koroneiki cultivar.
\end{abstract}

Keywords: olive trees, irrigation management, water stress, chlorophyll fluorescence

*e-mail: abderrahman.sghaier@gmail.com 


\section{Introduction}

Climate change poses a significant challenge for the entire global world. It's mainly translated by an increase in temperature and a decrease in rainfall [1]. Thus it has different effects on environmental degradation, water efficiency, and agricultural productivity [2-4]. Potential effects of predicted changes are more dramatic for arid and semi-arid regions. Reduced water availability is among major environmental factors that can greatly affect plant production [5]. The most vulnerable plants, under extreme drought conditions, are those slow to adapt - like perennial fruit trees [6]. One of the most important perennial crops at risk in the Mediterranean region is the olive tree [7] (Olea Europea L.), which is native to the Mediterranean basin that has considerable socio-economic importance. Olive is cultivated in rainfall conditions due to its minimal requirements in water [8]. Olive is well adapted to overcome water shortages. However, the ability of the olive tree to adapt to different drought conditions involves a metabolic cost characterized by the diversion of reserves from growth and a reduction in leaf area, which cause a significant reduction in productivity [9]. On the other hand, the severity of future drought projections due to fast global environmental change puts the olive in serious danger [10]. So it is necessary to adapt olive crops to a situation of sustainability that obtains a certain trade-off between productivity and water availability.

In recent decades, several studies have been carried out to propose solutions to grow olives under water scarcity so that we can adapt olive crops to a situation of sustainability that obtains a certain tradeoff between productivity and water availability. Most of those studies focused either on comparing different deficit irrigation levels on olive tree [11-13], comparing how different genotypes cope with water stress [1416], or on the physiological response to sustained water deficit and subsequent re-watering [17, 18], despite many studies having shown that irrigation frequency affects photosynthesis, leaf gas exchange, vegetative growth, and yield of other species under water stress [19]. The effect of irrigation frequency has not yet been studied on vegetative growth and olive tree yield. The aim of this study was to evaluate the effect that irrigation frequency has on vegetative growth, leaf turgor pressure, and fluorescence of olive tree (Olea europaea L.) cultivars Koroneiki and Picholine.

\section{Material and Methods}

\section{Experimental Setup}

One-and-a-half-year-old rooted cuttings of the olive (Oleaeuropaea L.) cultivars Koroneiki and Picholine were grown in $20-\mathrm{L}$ plastic pots containing freely drained light soil, with a $\mathrm{pH}$ of 7.6 , a field capacity of $35 \%$, and permanent wilting point of $15 \%$ in a greenhouse at the specialized unite the Olive Tree Institute of Sousse in Tunisia (35'49'34”N; $\left.10^{\circ} 38^{\prime} 24^{\prime \prime} \mathrm{E}\right)$ from March to November 2015. During the experiment, the plants continued to grow without particular problems.

The experiment was laid out following a split-plot design; the main plot units had a $3 * 2$ factorial design with three irrigation frequencies and two olive cultivars. Irrigation frequency was the main factor. The split-plot units within each main plot consisted of five olive trees.

Irrigation was designed to deliver $100 \%$ of the available water content (AWC). The irrigation treatments consisted of irrigating every other day (T0), and irrigating every 4 days (T1) and every 8 days (T2).

\section{Measurement Methods}

\section{Soil Moisture}

The volumetric water content of the soil $(\theta \mathrm{v})$ was measured using an SM150T soil moisture (Delta-T Devices Ltd., Cambridge,UK) probe every other day throughout the experiment period for all pots. It was measured with a soil moisture sensor.

\section{Plant Growth and Environmental Measurements}

Apical growth was measured every 2 weeks from the $15^{\text {th }}$ of May to the $15^{\text {th }}$ of November 2015. The measurements were performed on all the trees.

Air temperature and relative humidity in the greenhouse were measured instantaneously throughout the period of the experiment using sensors installed in the middle of the greenhouse. The data was saved by a data logger equipped with a wireless transmitter connected to a control unit in the laboratory.

\section{Leaf Turgor Pressure}

Two trees per treatment were equipped with an LPCP probe (probes provided by ZIM Plant Technology $\mathrm{GmbH}$, Hennigsdorf, Germany). The probes were clamped on leaves on the Northeast side of the tree. Installation was done as recommended by Zimmermann [20]. The output pressure probes were adjusted to be between 10 and $25 \mathrm{kPa}$ by adopting an appropriate distance between the two magnets. The probes were clamped between the central nerve and the leaf margins to establish a uniform contact with the leaf tissue. The magnets containing the pressure sensor were placed on the abaxial leaf surface. Probes pressure recordings were sent every 5 minutes via a wireless transmitter to a base station, which is connected to an Internet server of the company ZIM Plant Technology GmbH. This allows monitoring and control of experimentation through any computer connected to the Internet. Certain probes were accidentally detached because of the usual work in the greenhouse. Also, wind and dust accumulation caused poor contact between the probes 
and leaves. This malfunction of the probes led to the loss of data from these probes for short periods. In these cases, the probes were removed, cleaned, and attached to the leaves well.

Fernandez [21] revealed a correspondence between the midday stem water potential ( $\psi$ swp) and changes of the $\mathrm{Pp}$ value over a period of several days. He found three states of stress corresponding to three specific ranges of $\psi$ swp. Furthermore, Ehrenberger [22] characterized these states with more details:

- State 1: low water stress, the leaf is in a turgescent state characterized by a reciprocal dependency of Pp on turgor pressure $(\mathrm{Pc}$ values larger than $50 \mathrm{kPa})$. This state corresponded to a $\psi$ sw under $-1.2 \mathrm{MPa}$.

- State 2: moderate water stress, the turgor pressure in the leaf is low. This state is characterized by an unfavorable ratio of air to water in the leaf. It represents an intermediate state between States 1 and 3 , and the Pp curve is semi-inversed. It corresponded to a $\psi$ sw ranging from -1.2 to $-1.7 \mathrm{MPa}$.

- State 3: severe water stress, the leaf is significantly dehydrated (air is accumulated in the leaf tissue) and the turgor pressure values close to zero: this state is denoted by the inversion of the Pc curves (Pp records minimum values at noon and maximum values during the night). This state corresponded to a $\psi \mathrm{sw}$ below $-1.7 \mathrm{MPa}$.

\section{Photochemical Efficiency of PSII}

The fluorescence parameters (F0: initial fluorescence and Fm: maximal fluorescence) were measured with a mobile chlorophyll fluorometer (OS1-FL OptiSciences) on two leaves by olive-tree and two olivetrees by irrigation treatment [23]. These parameters were taken at noon at a suitable angle for ambient light to penetrate up to the leaf surface. The probe is kept stable during measurements to avoid disturbance [24]. The photochemical efficiency of photosystem II (PS II) was estimated from a ratio of variable fluorescence to maximum fluorescence $(\mathrm{Fv} / \mathrm{Fm}=(\mathrm{Fm}-\mathrm{F} 0) / \mathrm{Fm})[25]$.

\section{Statistical Analysis}

A two-way analysis of variance (ANOVA) was used to examine the effect of cultivars and doses of irrigation on all parameters studied. The differences between irrigation treatments were compared using Tukey's test calculated at $\mathrm{p}<0.05$. These analyses were performed using SPSS 16.0 statistical software for Windows (SPSS, Chicago, IL).

\section{Results and Discussion}

The effect of irrigation frequency and olive cultivar on the photochemical efficiency of PSII $(\mathrm{Fv} / \mathrm{Fm})$ and vegetative growth was studied through two-way ANOVA. The interaction between factors was non-

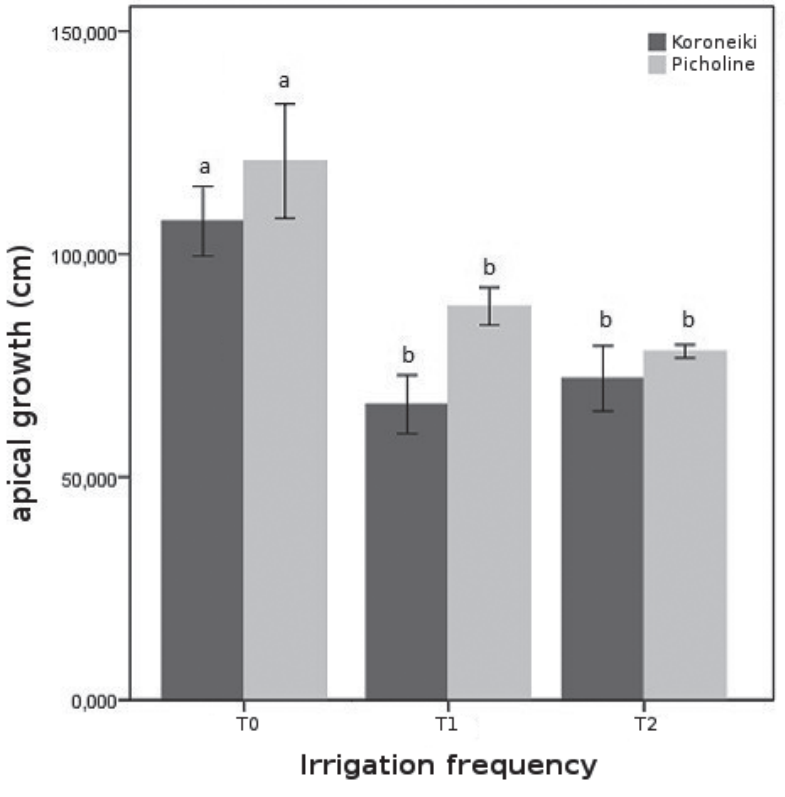

Fig. 1. Average apical growth of the two olive cultivars (Koroneiki and Picholine) at irrigation frequencies T0, T1, and T2 (means with the same letter are not significantly different at $\mathrm{P} \leq 0.05)$

significant for nearly all dates and times in the day, so their effect can be assumed to be independent enough to allow the study of each factor separately.

For frequencies $\mathrm{T} 1$ and $\mathrm{T} 2$, the Koroneiki cultivar showed a close vegetative growth rate (Fig. 1).

These results were supported by the results of leaf turgor pressure (Koroneiki cultivar showed state 3 under both T1 and T2 treatments; Fig. 2).

Picholine, on the other hand, showed a significant difference depending on the irrigation schedule. Thus for this cultivar, the growth rate was in clear correlation with the water treatment. These results fit with the results of the leaf turgor pressure for this cultivar where state 3 appeared only in trees under T3 treatment. The vegetative growth in Picholine cultivar is consistent with that found by Aïachi-Mezghani [26]. Irrespective of the time lag between irrigation, Picholine cultivar showed growth rates higher than the Koroneiki cultivar. Those higher rates can be explained by the genetic background of each cultivar [27]. Moreover, Picholine appears to have higher rates even when subjected to water stress $[16,28$, 29]. The different growth dynamic may be due to the different adaptation strategies adopted by different olive cultivars [30]. The Picholine cultivar showed more acute signs of stress when there are extreme environmental conditions. Despite that, the overall physiological responses to water shortage had less important effects on it. Therefore, for that cultivar the inactivation of Rubisco and the inhibition of photochemical reactions may interfere in the process of the inhibition of the photosynthesis. However, the stomatal closure has the greatest impact on the photosynthesis inhibition for Koroneiki cultivar [16, 28]. This is supported clearly 
a)
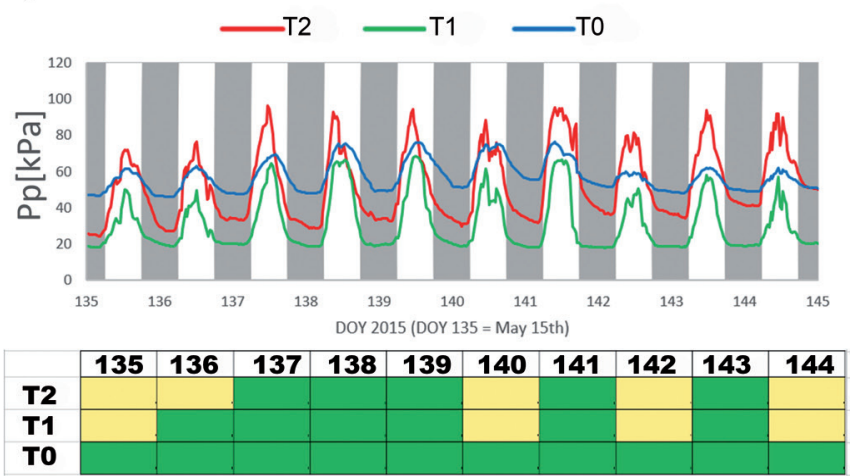

c)
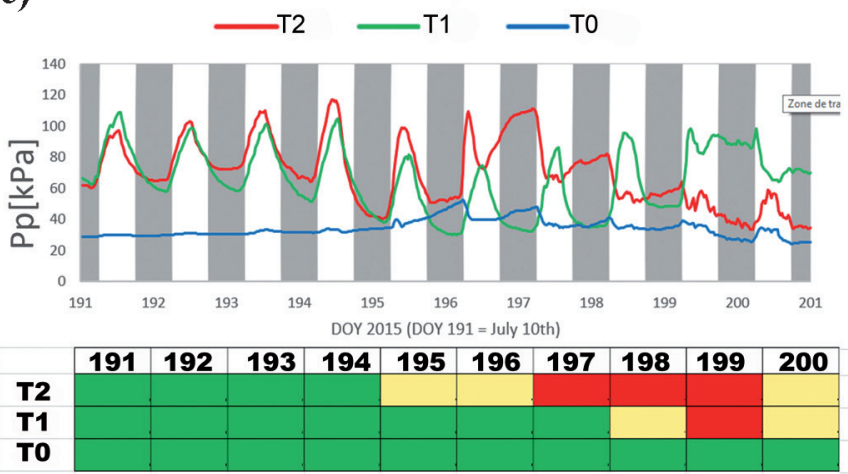

e)
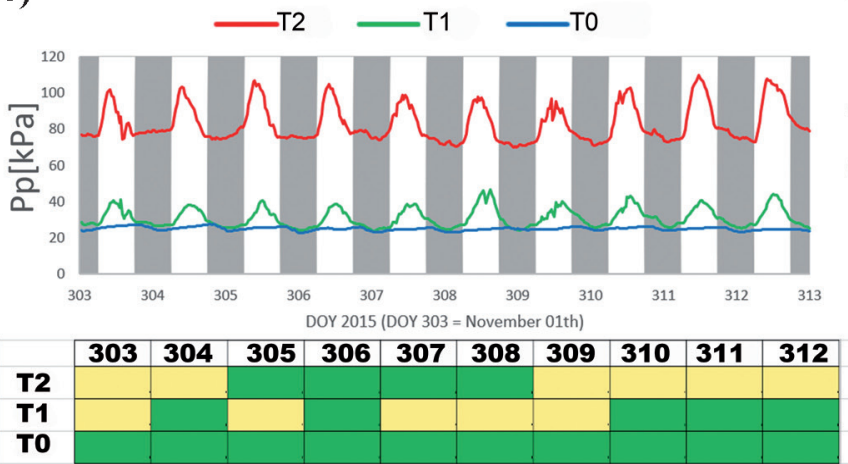

b)

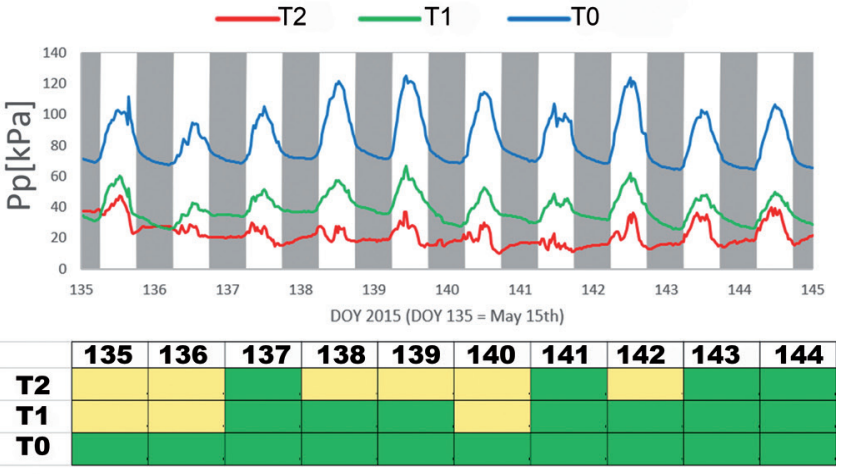

d)

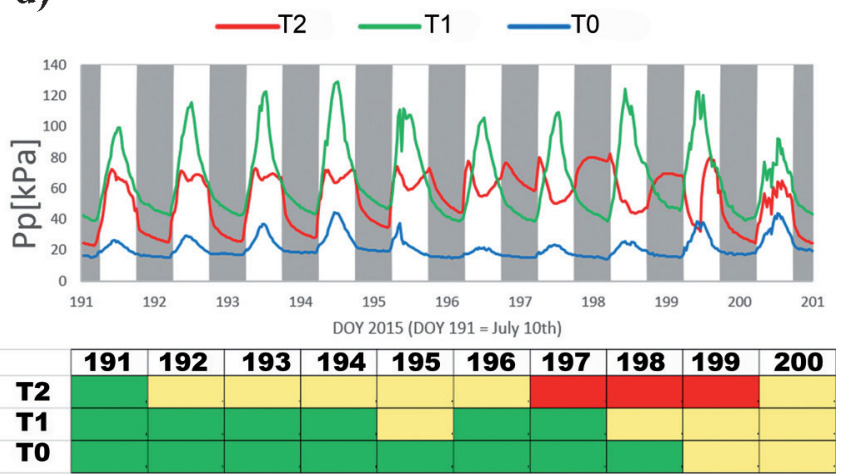

f)

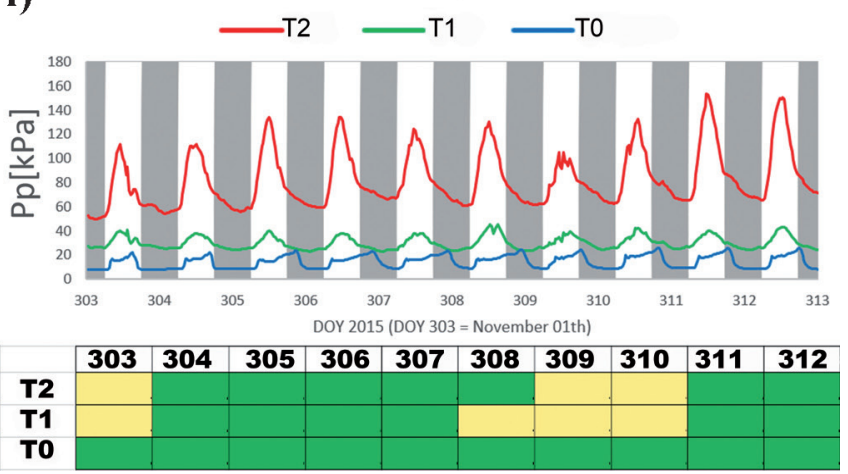

Fig. 2. Daily curves of the output probe's pressure (Pp) in Koroneiki (a, c, and e) and Picholine (b, d, and f) cultivars for frequency of irrigations T0, T1, and T2; the tree state per irrigation treatment and cultivar are shown here by horizontal color bars through State 1 (low water stress: green), State 2 (moderate stress: yellow), and State 3 (severe stress: red).

by the result of the soil moisture, where means of soil moisture are higher in pots of Koroneiki cultivar than in pots of Picholine for all irrigation frequencies (Fig. 3 ). The lack of correlation between the growth rate and the water treatment among the Koroneiki cultivar can be explained by the effect of annual alternation, which can be accentuated under water deficit conditions [31].

As discussed by Fernández [32], the ZIM system is a practical technique for monitoring water stress. In addition, it is capable of detecting the stress in early stages when it was still possible to prevent their effects on growth [17, 33, 34].

The result of the leaf turgor pressure shows significant changes in both absolute values and $\mathrm{Pp}$ curves depending on the season. Fig. 2 represents a Part of the long-term Pp measurements recorded during the three seasons of the experimentation for Picholine and Koroneiki.

During the springtime, a high positive correlation was recorded between the pressure peaks of leaf turgidity (TFP) and water treatment in both cultivars. The peaks of diurnal pressure, the minimum values of nocturnal pressure, and amplitudes of leaf turgor pressure are indicators of moderate water stress [35]. For $\mathrm{T} 1$ these indicators were very close to the control treatment (T0) in both cultivars. They are similar to that recorded by Ehrenberge [22] in non-stressed trees. In addition, the irrigation event in the fourth day induces a slight decrease in both diurnal and nocturnal extremities for both cultivars. This result suggests that treatment $\mathrm{T} 1$ does not induce stress in suitable climatic conditions. For the irrigation schedule T2, the daily means of turgor 

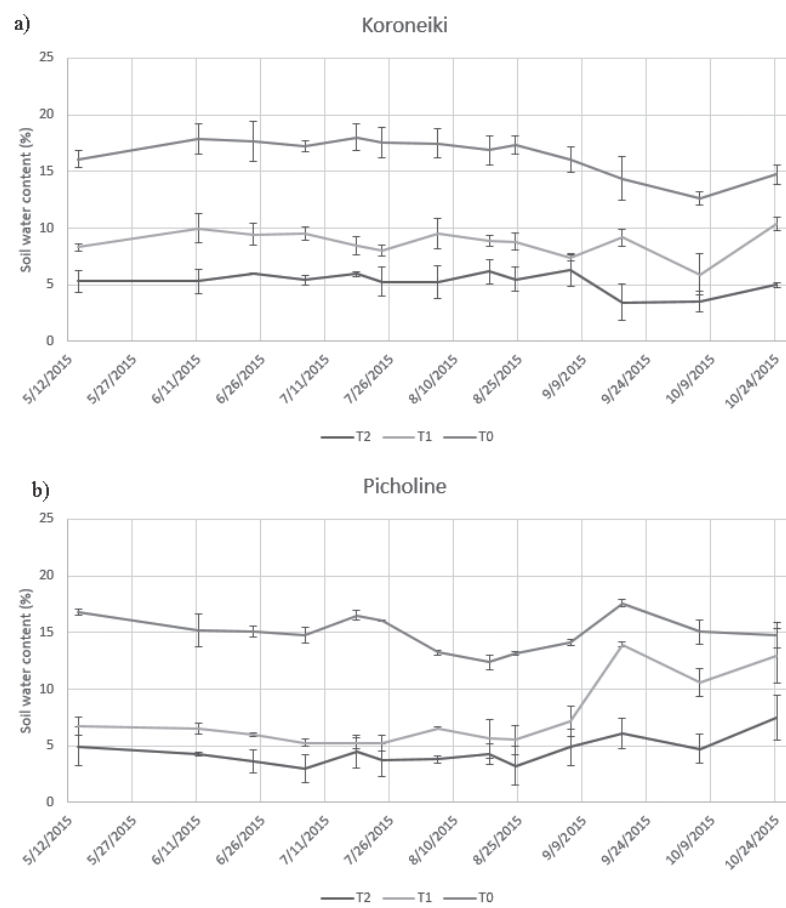

Fig. 3. Changes in soil water content (\%) in Koroneiki a) and Picholine b).

pressure was higher for both cultivars. In the sixth and seventh days after irrigation, daytime peak pressures increased to reach values over $80 \mathrm{kPa}$ and basic turgor recorded values close to $50 \mathrm{kPa}$, indicating moderate stress state $[21,36]$. In addition, the rate of the decrease in patch pressure afternoon peaking rises along with the decrease in water content. According to Bramley [37], this indicates slight water stress. Therefore, state one was observed in the majorities of the days and state two was observed a few days before re-watering. In both irrigation frequencies $\mathrm{T} 1$ and $\mathrm{T} 2$, the trees recover quickly after irrigation and return to state one.

During the summer, when the temperature can reach $50^{\circ} \mathrm{C}$, Koroneiki and Picholine exhibited different reactions. Picholine cultivar under T1 treatment showed that extreme temperature only induces an increase in both daytime peak pressures and basic turgor following the irrigation schedule. However, Koroneiki under the same water treatment showed that as it becomes more difficult for leaves to rehydrate with increasing soil water deficit, $\mathrm{Pp}$ values recorded a peak value during the afternoon, followed by an increase during the night - a phenomenon known as semi-inversion of the Pp curve [38]. Even though this is reversible when the plant rehydrates depending on the schedule, it can affect the productivity of the plan [39]. Unsurprisingly, under treatment T2 where the rehydration of trees was less frequent, both cultivars recorded minimum values during daytime, which can be explained by large air spaces in the leaf and a maximum value during nighttime due to the reduction of the air spaces volume by some water. This behavior indicates a full inversion of the Pp curve. As the semi-inversion, the full-inversion is reversible too [40]. Nevertheless, if the plant did not rehydrate soon, permanent damage can occur. This phenomenon was more frequent in Koroneiki cultivar. The reason behind this behavior could be the tendency of the Koroneiki cultivar to have less dense mesophyll cells compared to other cultivars when subjected to water stress [16]. Hence, there are more air spaces in the spongy mesophyll tissue in Koroneiki's leaves, which is the main reason for the inverse diurnal $\mathrm{Pp}$ curves [40]. Nevertheless, if the plant did not rehydrate soon, permanent damage can occur. This phenomenon was more frequent in Koroneiki cultivar. The reason behind this behavior could be the tendency of the Koroneiki cultivar to have less dense mesophyll cells compared to other cultivars when subjected to water stress [16]. Hence, there are more air spaces in the spongy mesophyll tissue in Koroneiki leaves, which is the main reason for the inverse diurnal Pp curves [40].

During autumn, $\mathrm{Pp}$ curves showed a pattern similar to that recorded during the spring. Thus, state one was dominant within a few days of state two. However, the Pp recorded values higher than expected. This can be explained by the changes in the structure and the mechanical characteristics of the olive leaf throughout the experiment. Thus, as the experiment was conducted during a relatively long and stressful period, the absolute Pp values may be affected by the damaged palisade parenchyma due to water stress [34].

Picholine cultivar shows averages of the photochemical efficiency of PSII ( $\mathrm{Fv} / \mathrm{Fm})$ between 0.658 and 0.851 , while averages of the photochemical efficiency of PSII $(\mathrm{Fv} / \mathrm{Fm})$ for the Koroneiki cultivar appear between 0.696 and 0.843 (Fig. 4). During spring and autumn, the photochemical efficiency was higher in Picholine cultivar than in Koroneiki. On the other hand, during summer the fluorescence activity was more affected in Picholine cultivar. These results fit with the result of vegetative growth, leaf turgor pressure, and soil water content. This photochemical efficiency behavior supports the suggestion given above that the inhibition of photochemical reactions has a greater impact on limiting the development of this cultivar. The photochemical efficiency for the Koroneiki cultivar appeared to be less sensitive to the season rather than the water treatment. These results show clear accordance with the results discussed above. From the results obtained in both cultivars, during the summer there was a dramatic decrease in the photochemical efficiency of PSII $(\mathrm{Fv} / \mathrm{Fm})$ proportional to water availability (Fig. 4). The same phenomenon was observed in the work in other olive cultivars [41]. Any time this reduction was greater in the Picholine cultivar. According to Angelopoulos [18] and Sofo [42], such as the reduction of the ratio (Fv/ Fm), shows that the plant is under a severe water stress, which can induce a certain level of photo-inhibition. The tree can recover partially four to five days after reirrigation. 

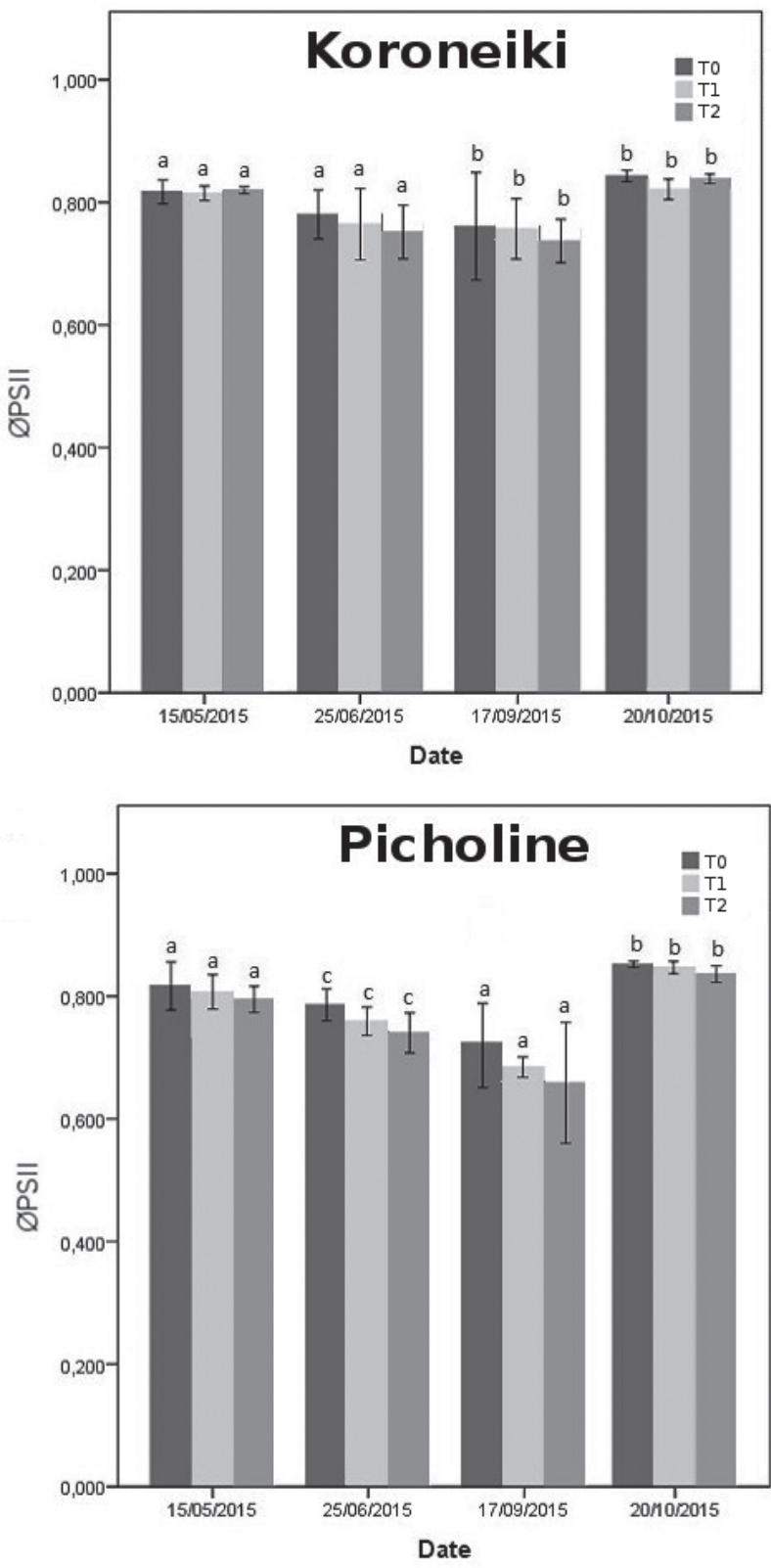

Fig. 4. Change in means of photochemical efficiency of PSII in Koroneiki and Picholine cultivars (means with the same letter are not significantly different at $\mathrm{P} \leq 0.05$ ).

\section{Conclusions}

The leaf turgor pressure revealed coherence with the results of vegetative growth and soil moisture. However, signs of stress for the photochemical efficiency of PSII manifested slower than other parameters, along with the water scarcity in the soil. As fluorescence-based measurements are considered to be a sensitive element of the photosynthesis system, the slower response of photochemical efficiency can be explained by the ability of the olive tree to maintain normal photosynthesis productivity rate under stresscausing conditions for a prolonged time.

\section{Conflict of Interest}

The authors declare no conflict of interest.

\section{References}

1. Intergovernmental panel on climate change. Impacts, Adaptation and Vulnerability: Regional Aspects. Cambridge University Press, 2014.

2. SCHLENKER W., LOBELL D.B. Robust negative impacts of climate change on African agriculture. Environmental Research Letters, 5 (1), 014010, 2010.

3. MÜlleR C., CRAMER W., HARE W.L., LOTZECAMPEN H. Climate change risks for African agriculture. Proceedings of the National Academy of Sciences, 108 (11), 4313, 2011.

4. Intergovernmental panel on climate change. Climate change 2014: mitigation of climate change. Cambridge University Press, 2015.

5. PITTELKOW C.M., LIANG X., LINQUIST B.A., VAN GROENIGEN K.J., LEE J., LUNDY M.E., VAN GESTEL N., SIX J., VENTEREA R.T., VAN KESSEL C. Productivity limits and potentials of the principles of conservation agriculture. Nature, 517 (7534), 365, 2015.

6. LOBELL D.B., FIELD C.B., CAHILL K.N., BONFILS C. Impacts of future climate change on California perennial crop yields: Model projections with climate and crop uncertainties. Agricultural and Forest Meteorology, 141 (2), 208, 2006.

7. QUIROGA S., SUÁREZ C. Climate change and drought effects on rural income distribution in the Mediterranean: a case study for Spain. Natural Hazards and Earth System Sciences, 16 (6), 1369, 2016.

8. HASSINE M.B., BOUSSADIA O., ABDELKADER A.B., MOULA I., EL HAFI M., BRAHAM M. Water use efficiency of olive tree under two water treatments in Tunisian semi-arid conditions. Arabian Journal of Geosciences, 10 (14), 302, 2017.

9. PEREZ-MARTIN A., MICHELAZZO C., TORRES-RUIZ J.M., FLEXAS J., FERNÁNDEZ J.E., SEBASTIANI L., DIAZ-ESPEJO A. Regulation of photosynthesis and stomatal and mesophyll conductance under water stress and recovery in olive trees: correlation with gene expression of carbonic anhydrase and aquaporins. Journal of experimental botany, 65 (12), 3143, 2014.

10. SOFO A., PALESE A.M., CASACCHIA T., DICHIO B., XILOYANNIS C. Sustainable fruit production in Mediterranean orchards subjected to drought stress. Abiotic Stress Responses in Plants: Springer. 105, 2012.

11. MASMOUDI M., BESBES S., BLECKER C., ATTIA H. Preparation and characterization of jellies with reduced sugar content from date (Phoenix dactylifera L.) and lemon (Citrus limon L.) by-products. Fruits, 65 (1), 21, 2010.

12. INIESTA F., TESTI L., ORGAZ F., VILLALOBOS F. The effects of regulated and continuous deficit irrigation on the water use, growth and yield of olive trees. European Journal of Agronomy, 30 (4), 258, 2009.

13. RAMOS A.F., SANTOS F.L. Water use, transpiration, and crop coefficients for olives (cv. Cordovil), grown in orchards in Southern Portugal. biosystems engineering, 102 (3), 321, 2009. 
14. ENNAJEH M., VADEL A., COCHARD H., KHEMIRA H. Comparative impacts of water stress on the leaf anatomy of a drought-resistant and a drought-sensitive olive cultivar. The Journal of Horticultural Science and Biotechnology, 85 (4), 289, 2010.

15. GUERFEL M., BACCOURI O., BOUJNAH D., CHAÏBI W., ZARROUK M. Impacts of water stress on gas exchange, water relations, chlorophyll content and leaf structure in the two main Tunisian olive (Olea europaea L.) cultivars. Scientia Horticulturae, 119 (3), 257, 2009.

16. BOSABALIDIS A.M., KOFIDIS G. Comparative effects of drought stress on leaf anatomy of two olive cultivars. Plant science, 163 (2), 375, 2002.

17. AISSAOUI F., CHEHAB H., BADER B., SALEM A.B., M'BARKI N., LAAMARI S., CHIHAOUI B., MAHJOUB Z., BOUJNAH D. Early water stress detection on olive trees (Olea europaea L. cvs 'chemlali'and 'Chetoui') using the leaf patch clamp pressure probe. Computers and Electronics in Agriculture, 131, 20, 2016.

18. ANGElOPOUlOS K., DICHIO B., XILOYANNIS C. Inhibition of photosynthesis in olive trees (Olea europaea L.) during water stress and rewatering. Journal of Experimental Botany, 47 (8), 1093, 1996.

19. SEBASTIAN B., BAEZA P., SANTESTEBAN L.G., DE MIGUEL P.S., DE LA FUENTE M., LISSARRAGUE J.R. Response of grapevine cv. Syrah to irrigation frequency and water distribution pattern in a clay soil. Agricultural Water Management, 148, 269, 2015.

20. ZIMMERMANN U., RÜGER S., SHAPIRA O., WESTHOFF M., WEGNER L., REUSS R., GESSNER P., ZIMMERMANN G., ISRAELI Y., ZHOU A. Effects of environmental parameters and irrigation on the turgor pressure of banana plants measured using the non-invasive, online monitoring leaf patch clamp pressure probe. Plant Biology, 12 (3), 424, 2010.

21. FERNÁNDEZ J., RODRIGUEZ-DOMINGUEZ C., PEREZ-MARTIN A., ZIMMERMANN U., RÜGER S., MARTÍN-PALOMO M., TORRES-RUIZ J., CUEVAS M., SANN C., EHRENBERGER W. Online-monitoring of tree water stress in a hedgerow olive orchard using the leaf patch clamp pressure probe. Agricultural Water Management, 100 (1), 25, 2011.

22. EHRENBERGER W., RÜGER S., RODRÍGUEZDOMÍNGUEZ C., DÍAZ-ESPEJO A., FERNÁNDEZ J., MORENO J., ZIMMERMANN D., SUKHORUKOV V., ZIMMERMANN U. Leaf patch clamp pressure probe measurements on olive leaves in a nearly turgorless state. Plant Biology, 14 (4), 666, 2012.

23. ROHÁČEK K. Chlorophyll fluorescence parameters: the definitions, photosynthetic meaning, and mutual relationships. Photosynthetica, 40 (1), 13, 2002.

24. MURCHIE E.H., LAWSON T. Chlorophyll fluorescence analysis: a guide to good practice and understanding some new applications. Journal of experimental botany, 64 (13), 3983, 2013.

25. MAXWELL K., JOHNSON G.N. Chlorophyll fluorescence - a practical guide. Journal of experimental botany, 51 (345), 659, 2000.

26. MEZGHANI M.A., CHARFI C.M., GOUIAA M., LABIDI F. Vegetative and reproductive behaviour of some olive tree varieties (Olea europaea L.) under deficit irrigation regimes in semi-arid conditions of Central Tunisia. Scientia horticulturae, 146, 143, 2012.
27. BANDELJ D., JAKŠE J., JAVORNIK B. Assessment of genetic variability of olive varieties by microsatellite and AFLP markers. Euphytica, 136 (1), 93, 2004.

28. AIACHI-MEZGHANI M., MASMOUDI-CHARFI C., ZOUARI I., LABIDI F., ATTIA L., GOUIAA M. Responses of Olive Varieties to Restrictive Water Regimes. Olivebioteq 2014, 241, 2014.

29. MOUNA A.M., ALI S., NAZIHA G., BADII G., IBTISSEM L. Growth, yield responses and water relations of different varieties (Olea europaea L.) cultivated under two water conditions in semi-arid conditions of Tunisia. European Scientific Journal, ESJ, 10 (15), 2014.

30. LAVEE S., HANOCH E., WODNER M., ABRAMOWITCH H. The effect of predetermined deficit irrigation on the performance of $\mathrm{cv}$. Muhasan olives (Oleaeuropaea L.) in the eastern coastal plain of Israel. Scientia Horticulturae, 112 (2), 156, 2007.

31. BUSTAN A., AVNI A., LAVEE S., ZIPORI I., YESELSON Y., SCHAFFER A.A., RIOV J., DAG A. Role of carbohydrate reserves in yield production of intensively cultivated oil olive (Olea europaea L.) trees. Tree physiology, 31 (5), 519, 2011.

32. FERNÁNDEZ J. Plant-based sensing to monitor water stress: Applicability to commercial orchards. Agricultural water management, 142, 99, 2014.

33. MARINO G., PERNICE F., MARRA F.P., CARUSO T. Validation of an online system for the continuous monitoring of tree water status for sustainable irrigation managements in olive (Olea europaea L.). Agricultural Water Management, 177, 298, 2016.

34. PADILLA-DÍAZ C., RODRIGUEZ-DOMINGUEZ C., HERNANDEZ-SANTANA V., PEREZ-MARTIN A., FERNÁNDEZ J. Scheduling regulated deficit irrigation in a hedgerow olive orchard from leaf turgor pressure related measurements. Agricultural Water Management, 164, 28, 2016.

35. RÜGER S., EHRENBERGER W., AREND M., GESSNER P., ZIMMERMANN G., ZIMMERMANN D., BENTRUP F.-W., NADLER A., RAVEH E., SUKHORUKOV V. Comparative monitoring of temporal and spatial changes in tree water status using the non-invasive leaf patch clamp pressure probe and the pressure bomb. Agricultural water management, 98 (2), 283, 2010.

36. ZIMMERMANN D., REUSS R., WESTHOFF M., GESSNER P., BAUER W., BAMBERG E., BENTRUP F.-W., ZIMMERMANN U. A novel, non-invasive, online-monitoring, versatile and easy plant-based probe for measuring leaf water status. Journal of Experimental Botany, 59 (11), 3157, 2008.

37. BRAMLEY H., EHRENBERGER W., ZIMMERMANN U., PALTA J.A., RÜGER S., SIDDIQUE K.H. Noninvasive pressure probes magnetically clamped to leaves to monitor the water status of wheat. Plant and soil, 369 (1-2), 257, 2013.

38. FERNÁNDEZ J.-E. Understanding olive adaptation to abiotic stresses as a tool to increase crop performance. Environmental and Experimental Botany, 103, 158, 2014.

39. HADIDDOU A., OUKABLI A., MOUDAFFAR C., MAMOUNI A., GABOUN F., MEKAOUI A., H'SSAINI L., EL FECHTALI M. Evalution des performances de production de 14 variétés d'olivier (Olea europaea L.) Nationales et méditerranéennes dans deux systèmes 
contrastés de culture (pluvial et irrigué) au Maroc. Al Awamia, 127, 22, 2013.

40. EHRENBERGER W., RÜGER S., FITZKE R., VOLLENWEIDER P., GÜNTHARDT-GOERG M., KUSTER T., ZIMMERMANN U., AREND M. Concomitant dendrometer and leaf patch pressure probe measurements reveal the effect of microclimate and soil moisture on diurnal stem water and leaf turgor variations in young oak trees. Functional Plant Biology, 39 (4), 297, 2012.
41. SOFO A., MANFREDA S., FIORENTINO M., DICHIO B., XILOYANNIS C. The olive tree: a paradigm for drought tolerance in Mediterranean climates. Hydrology and Earth System Sciences Discussions, 12 (1), 293, 2008.

42. SOFO A. Drought stress tolerance and photoprotection in two varieties of olive tree. Acta Agriculturae Scandinavica, Section B-Soil \& Plant Science, 61 (8), 711, 2011. 